\title{
İlköğretim okullarında uygulanan stratejik planlamanın yönetici-öğretmen görüşleri ve izleme raporlarına göre değerlendirilmesi ${ }^{*}$
}

\author{
Necmi GÖKYER ${ }^{* *}$ \\ Muhammed ZİNCÍRLİ**
}

\begin{abstract}
Özet
\end{abstract}
Eğitim planlaması; amaçları, belli seçim önceliklerine göre sıralayan ve kaynakları bu öncelikli amaçlara dağıtan mekanizma olarak tanımlanabilir. Stratejik planlama da bize hangi noktada olduğumuzu ve neler yapmamız gerektiği hakkında yol haritası olacaktır. Eğitim hizmeti gibi planlama faaliyetlerinin önemli olduğu bir konuda, stratejik planlama önemini daha da arttırmaktadır. $\mathrm{Bu}$ çalışmanın amacı, ilköğretim kurumlarındaki stratejik planlamanın uygulanabilirliğinin yönetici ve öğretmen görüşlerine göre değerlendirmektir. Bu araştırma "tarama modeli” olarak tasarlanmıştır. Ayrıca araştırmada stratejik planlamanın ilköğretim kurumlarında değerlendirmesini yapmak için her kurumun kendi planına ait olan izleme raporları incelenmiştir. Elazığ il merkezine bağlı ve tüm ilçe merkezlerindeki ilköğretim kurumları araştırmanın evrenini oluşturmaktadır. Veri toplama araçları evrendeki 3323 öğretmen ve 354 yöneticiden 850 öğretmen ve 104 yöneticiye dağıtılmıştır. Geri dönen 535 öğretmen ve 102 yöneticiye ait ölçek üzerinden analizler yapılmıştır. Analizler için; frekans, yüzde, ortalama, standart sapma, Pearson Korelasyon katsayısı hesaplanmış, Mann Whitney U testi ve Kruskal Wallis testi yapılmıştır. Araştırmanın sonuçlarına göre, eğitim düzeyi arttıkça öğretmenlerin stratejik planın hazırlanma süreci boyutuna ilişkin görüşleri olumluya doğru yükselmektedir. Stratejik planlama ile ilgili eğitim almış olan öğretmenlerin stratejik planın okula kazandırdıkları boyutuna ilişkin görüşleri diğerlerine göre daha olumlu şekilde belirlenmiştir. Yöneticilerin \%70’i stratejik planlama ile ilgili eğitim almamışlardır. 2011 yılı stratejik plan izleme raporlarına ait 105 performans göstergesi ve faaliyetten 55’i (\%53) tamamlanmıştır. Bununla birlikte, aynı örneğe ait 11 ilköğretim okulunun 2011 stratejik plan izleme raporları analiz edilip sonuçları tablolarda verilmiştir.

Anahtar kelimeler: Stratejik planlama, ilköğretim, yönetici, öğretmen, izleme raporları

* Bu çalışma; Muhammed Zincirli tarafından Doç. Dr. Necmi Gökyer danışmanlığında tamamlanan "İlköğretim okullarında stratejik planlamanın uygulanabilirliğini yönetici-öğretmen görüşleri ve izleme raporlarına göre değerlendirilmesi” başlıklı yüksek lisans tez çalışmasından üretilmiştir.

** Doç. Dr., Fırat Üniversitesi, Eğitim Fakültesi, Eğitim Bilimleri Bölümü, ngokyer@firat.edu.tr

*** Doktora Öğrencisi, Fırat Üniversitesi, Eğitim Fakültesi, Eğitim Bilimleri Enstitüsü, mzincirli@firat.edu.tr 


\title{
The evaluation of practicality of strategic planning in primary schools according to administrators-teachers' views and monitoring reports
}

\begin{abstract}
Educational planning might be defined as a mechanism, which arranges the objectives, based on priorities of certain choices and distributes the relevant sources to the primary objectives. A good planning is needed for education to achieve the target. Prospective planning is related to the success of its practicability. Putting forward highly practical plans requires determining the state of the current situation and knowing quite well where and how to act. Considering the importance of planning for education, setting a course for correct/effective planning is also very important. At this point, the need and importance of strategic planning for education stand out. Defining the goals, the routes to be followed to achieve those goals must be known through correct strategies. Strategic planning will be a route map to show where we are and what to do. Strategic planning includes all general research finding $s$ and objectives concerning relevant planning. The importance of strategic planning comes to surface when education services are considered. The study focuses on the importance of strategic planning in education. With this aim, the universe of the research includes the primary schools in Elazığ and in the districts of Elazığ. Data collection tools have been handed out to 3323 teachers and 354 administrators who were selected randomly among 850 teachers and 104 administrators. 535 teachers and 102 administrators' scales being handed in were evaluated. For analyzing; frequency, percentage, average, standard deviation, Pearson Correlation coefficient were calculated, Mann Whitney $U$ and Kruskal Wallis tests were used. According to the results of the search, the teachers' views of the process of preparing strategic planning are increasing as their educational level gets high. The views of the teachers, who got education about strategic planning, are higher on the gaining of strategic planning to the school when compared with the others. $70 \%$ of the administrators did not get an education about strategic planning. Of 105 performance indicators and activities of 2011 monitoring reports of strategic planning 55 (53\%) were completed. Besides this, the 2011 monitoring reports of strategic planning of 11 Primary schools belonging to the same sample have been analyzed and the results are presented in tables.
\end{abstract}

Keywords: Primary school, strategy, planning, administrator, teacher, monitoring reports

\section{Giriş}

Bilim ve teknoloji alanında meydana gelen bilgi patlaması, kısa sürede daha gelişmiş ürünlerin tüketime sunulması, iş gücü piyasanın rekabetçi ve yarışmacı doğası, bireysel iş yaşamı kalitesinin sürekli olarak gelişmesi tüm örgütleri etkilemekte, yenileşmeye ve değişmeye zorlamaktadır (Okutan, 2002, s. 6). Değişimi, dünyayı, sadece anlamak değil, bunlara müdahil de olabilmek gerekir. Bu nedenle değişimin yönetilmesi bir zorunluluk olmaktadır. Stratejik yönetim yaklaşımı, değişimin yönetilmesine ilişkin araçlar sunmaktadır. Bugün çok sayıda özel sektör, kamu kurum ve kuruluşları, sivil toplum kuruluşları, stratejik yönetim veya stratejik planlama kavramlarını değişimi yönetmenin bir aracı olarak görmekte ve kullanmaktadır (EARGED, 2007, s. 20). 
Strateji, çok uzun bir dönem askeri bir kavram olarak kullanılmıştır. Websters New International Dictionary’e göre; savaşta sonuca ulaşmak için karşıt tarafların askerî gücünü şartlara elverişli olarak yerleştirmesi, değiştirmesi bilimi ve sanatı olarak ifade edilmektedir (Üzün, 2000, s. 1). Bazı kaynaklar, stratejiyi Latince “yol, çizgi veya nehir yatağı” anlamındaki "stratum" kelimesinden geldiğini belirtmektedir (Mütercimler, 2006, s. 1). Strateji sözcüğünün kökeni, etimolojik acıdan ele alındığında, eski Yunancada "generallik sanatı" anlamına gelen "strategus" sözcüğüne bağlanmaktadır (Dedeoğlu, 2003, s. 25). Strateji genel anlamıla "sevk etme, yöneltme, gönderme, götürme ve gütme" demektir. Yine eski yunanlarda yunan generallerinden Strategos'un bilgi ve sanatına hitaben kullanılan bir kavram olduğu sanılmaktadır. Askeri özelliğini zamanla yitiren strategusluk makamı, M.Ö. 3. yüzyılda Mısır'da bir sivil valilik olarak yeniden ortaya çıktı ve Roma yönetimi altında M.S. 4. yüzyıla kadar varlığını korudu (Çelik, 1994, s. 30). Strateji kavramı için, birbirini tamamlayıcı özelliklere sahip farklı bakış açılarından tanımların yapılabilmesi de mümkündür. Bu tanımlar şu şekilde belirtilebilir (Akgemici, 2001, s. 3-4).

Plan olarak strateji: Eylem ve örgütlerin, bilinçli ve amaçlı olarak önceden tanımlanıp ilan edilmiş hedefler doğrultusuna yöneltilmesi.

Ortaya çıkan yön olarak strateji: Önceden tanımlanıp ilan edilmiş hedef doğrultusu yerine, ortamın duyarlılığı içinde örgütlerin tavır ve katılımları sonucu eylem yönünün ortaya çıkması.

Konum olarak strateji: Beklenti ve işlevlerin tanımladığı örgüt çevresi içinde örgütlerin yerlerini belirleyen, örgüt ile çevresi arasındaki ilişkiyi düzenleyen konum saptaması.

Bakış açısı olarak strateji: Ortak eylemde buluşan örgütlerin, ortak misyonları nedeni ile paylaştıkları normları, değerleri ve davranış kalıplarını içeren bakış açısı.

Bu ifadelerden yola çıkarak stratejiyi; “örgütün hangi işi yaptığını veya yapmak istediğini; ne tür bir örgüt olduğunu veya olmak istediğini tanımlayan amaç, hedef ve görevlerin tümü ve bunları gerçekleştirmek için gerekli yöntemlere verilen ad" olarak tanımlamak mümkündür (Üzün, 2000, s. 1). Stratejiyi “bir örgütü, amacı doğrultusunda fırsatçı yapan şey” biçiminde tanımlayan Drucker (1999), yirmi birinci yüzyıla girerken dünyanın içinde bulunduğu hızlı değişim ve belirsizlik ortamında, stratejinin aşağıdaki temellere dayandırılabileceği tezini savunmuştur:

- Gelişmiş dünyada düşmeye başlayan doğum oranı

- Kullanılabilir gelir dağılımındaki değişmeler

- Performansin yeniden tanımlanması

Stratejik yönetime geçişin bir aracı olan stratejik plan; kaynakların stratejik önceliklere göre dağıtılması ve uygulamaların buna göre sonuçlandırılması hususunda makro, sektörel, bölgesel ve yerel kriterler ile birlikte yönlendirici ve referans bir politika belgesi olacaktır. Stratejik planlama anlayışının eğitim-öğretim ve yönetimde etkin olmasını ve bir kültür olarak benimsenmesini 
sağlamak amacıyla Bakanlık için hazırlanan makro düzeydeki plana paralel olarak okul, ilçe ve il düzeyinde de stratejik planlar yapılması öngörülmüştür. MEB Stratejik Planı; bir yandan kurum kültürü ve kurum kimliği oluşumuna, gelişimine ve güçlendirilmesine destek olurken diğer yandan yönetim uygulamalarımıza idari ve mali yönden etkinlik kazandıracaktır (MEB 2010-2014 Stratejik Plan, 2009, s. 7). Stratejik planlama ayrıca, organizasyonunun zayıf yönlerini saptayarak bunların giderilmesine, güçlü olduğu yönlerinin de değerlendirilmesine olanak verir (MEB, 2005).

Stratejik planlama, yönetimin önemli bir aracıdır. Stratejik planlamanın böyle önemli olması nedeniyle kendi içinde bazı basamakları vardır. Her bir basamağın eksiksiz hazırlanıp uygulanması stratejik planlamanın uygulanabilirliği açısından önemlidir. Millı̂ Eğitim Bakanlığı, okulların tümünden stratejik planlama açısından çok ciddi çalışmalar yapmasını istemektedir. Bu amaçla 2010/14 sayılı ve 09.02.2010 tarihinde ilçe okul ve kurumlarda stratejik plan yapılmasına yönelik bir genelge yayınlamıştır. Stratejik planlama sayesinde okul yönetimleri ne durumda olduklarını tespit edebilme imkânı bulmuşlardır. Bu sayede okullarda yönetim veya personel değişse de mevcut durum ve ulaşılmak istenilen hedefler belirli olduğu için stratejik planlama geçerliliğini sürdürebilmelidir. Ayrıca şartlara göre planlamalar gerektiğinde revize edilmelidir.

\section{Eğitimde stratejik planlama}

Stratejik planlama evresinde okulun örgütsel kültürü, okulun birimleri arasındaki ilişkiler, örgütsel yapıdan kaynaklanan engeller ve okul-çevre ilişkileri analiz edilir. Daha sonra belirlenen yapıya en uygun strateji belirlenmeye çalışılır. Sonuç olarak stratejik planlama evresinde okulun nerede olduğu, nereye gitmek istediği ve oraya nasıl ulaşacağı belirlenir (Balc1, 1995, s. 171). Türkiye’nin hızlı değişim sürecinde ayakta kalabilmesi ve yenidünya düzeninde hak ettiği yerini alabilmesi için eğitim alanında köklü bir yeniden yapılanma hareketine zaman kaybetmeden başlanılması gerekmektedir. Yöneticiler yani eğitimde karar vericiler görevlerini başarı ile yerine getirebilmek için belirsizlikleri olabildiğince en aza indirgeyerek, gelecekteki eğilimleri ve olayları en iyi biçimde tahmin etmek durumundadırlar. Bunun için de eğitimin stratejik planlamasının en doğru süratle yapılıp uygulamaya geçirilmesi gerekmektedir (Küçüksüleymanoğlu, 2004, s. 2).

Eğitim stratejisini "amaçlarını gerçekleştirmeye çalışan bir eğitim kurumunun uygulayacağı hareket biçimi” olarak tanımlayabiliriz. Bu tanımlamalara göre, amaç, hedef ve görevler Millî Eğitim Temel Kanununda ve ilgili diğer kanunlarda belirlenmiştir (Şener, 2009, s. 65). Bu amaç ve görevleri gerçekleştirecek yöntemler ise eğitim kurumlarının kendi yönetmeliklerinde bulunmaktadır. Eğitimde stratejik planlama yapılırken uygulayacakların planlama sürecine katılmaları gerekmektedir. Uygulayıcıların planlama kararlarına katılmaması durumunda planlama modeli stratejik olmayacaktır. Stratejik planlamada uyum, anlaşma, inanç ve diyalog söz konusudur. Eğitimde stratejik planlama sürecinde önemli bir yere sahip olan stratejik planlama komitesinin plandan etkilenecek tüm kesimleri temsil eder nitelikte olması gerekir. Plandan etkilenecek kesimleri temsil etmeyen bir planlama komitesinin yapacağı planın stratejik olmayacağı açıktır (Kocatepe, 2010, s. 31).

Birimler ve iller kendilerine ait amaçları, hedefleri ve eylem planlarının uygulanmasının denetimi ve stratejik planların izleme raporları aracilığı ile değerlendirilebilmesi için kendi 
metotlarını geliştirebilirler. Dokümanın, her aşamanın durumunu belirtmesi gerekmektedir. Örneğin; iptal mi edildiği, planlama aşamasında mı olduğu veya gecikme mi olduğu gibi hususlar yer almalıdır. Ayrıca yorumlar içinde boş bir yer ayrılmalıdır. İzleme ve değerlendirme süreci kurumsal öğrenmeyi ve buna bağlı olarak faaliyetlerin sürekli olarak iyileştirilmesini sağlar. Ayrıca, hesap verme sorumluluğunun oluşturulmasına katkıda bulunur. Stratejik planın izleme ve değerlendirmeye tabi tutulması şarttır. Aksi takdirde, gerek planın uygulanmasında gerekse ilgililerin hesap verme sorumluluğu ilkesinin hayata geçirilmesinde zorluklarla karşılaşılacaktır (MEB, 2007).

Performansın izlenmesi, izleme faaliyetinin temelidir. Bunun için performans göstergeleri ile ilgili veriler düzenli olarak toplanmalı ve değerlendirilmelidir. Gerçek performansın "planlanan" performansla karşılaştırılması, stratejik plan ve planlama sürecinin periyodik bir şekilde değerlendirilmesini sağlayacaktır. Yönetim, beklenen sonuçlara ulaşılmaması durumunda üçer aylık veya aylık raporların sonuçlarını kullanarak sorunları saptar ve bu bilgileri kullanarak, ihtiyaç duyuyorsa, politikalarını, prosedürleri, amaç ve hedeflerini yeniden düzenler (MEB, 2007).

Plan dönemi içerisinde ve her yılın sonunda okul/kurum stratejik planı uyarınca yürütülen faaliyetler, önceden belirtilen performans göstergelerine göre hedef ve gerçekleşme durumu ile varsa meydana gelen sapmaların nedenlerinin açıklandığı, okul hakkında genel ve mali bilgileri içeren izleme ve değerlendirme raporu hazırlamaktadır. İzleme raporları haftalık, aylık, üçer aylık, altı aylık veya yıllık olabilir. Ancak faaliyet raporları yıllık olarak hazırlanmaktadır. Eylem planının yürütülmesinden sorumlu olan kişi ya da gruplar aynı zamanda da hedef ve amaçların yerine getirildiğini/getirilmediğini de izlemekle yükümlüdürler. İzleme, yönetime yardımcı olan sistemli bir faaliyettir. Raporlama izleme faaliyetinin temel aracıdır. İzleme raporları objektif olmalıdır. İlerleme sağlanan alanlar yanında, ilerleme sağlanamayan konular da rapor edilmelidir. Gözden geçirilmelerin üçer aylık ya da aylık periyotlar halinde yapılması idealdir (MEB, 2007).

$\mathrm{Bu}$ araştırmanın amacı, ilköğretim okullarındaki öğretmen ve okul yöneticilerinin stratejik planlamanın uygulanabilirliğine yönelik görüşlerini değerlendirmektir. Bu amaçla aşağıdaki sorulara yanıt aranmıştır:

- Stratejik planların uygulanabilirliğine yönelik yönetici görüşleri nelerdir?

- Stratejik planlamanın uygulanabilirliğine yönelik öğretmen görüşleri nelerdir?

• Yönetici ve öğretmen görüşlerinde "Branş”, "Kıdem”, "Eğitim durumu” ve "Stratejik planlama ile ilgili eğitim alma” değişkenlerine göre farklılık var mıdır?

\section{Yöntem}

\section{Araștırmanın modeli}

Bu araştırmada tarama modeli kullanılmıştır. Karasar (2009) Tarama modellerini geçmişte ya da halen var olan bir durumu var olduğu şekilde betimlemeyi amaçlayan araştırma yaklaşımları 
olarak tanımlamaktadır. Tarama modellerinde araştırmaya konu olan olay, birey ya da nesne, kendi koşulları içinde ve olduğu gibi tanımlanmaya çalışılır. Onları herhangi bir şekilde değiştirme, etkileme çabası gösterilmez. Araştırma modeli çerçevesinde yönetici ve öğretmenlerin stratejik planlamaların uygulanabilirliğine yönelik görüşleri incelenmiştir.

\section{Evren ve örneklem}

Araştırmanın evrenini Elazığ il merkezi ve ilçe merkezlerindeki ilköğretim okulları oluşturmaktadır. Bu okullar da toplam 3677 öğretmen ve okul yöneticisi (müdür, müdür yardımcısı) bulunmaktadır. Örneklem büyüklügünü hesaplamak için Cochran’n (1962; akt. Özmen, 1997) örneklem büyüklüğü belirleme formülü kullanılmıştır. Bu formülde \%95 güven düzeyi esas alınarak, örnekleme alınması gereken ilköğretim kurumlarında görev yapan öğretmenlerin ve yöneticilerin sayısı 348 olarak hesaplanmıştır. Araştırmanın örneklemi küme örnekleme yöntemine göre seçilmiştir. Dağıtılacak olan ölçek için küme örneklemesi yapılırken 2011-2012 eğitim-öğretim yılında Elazığ il merkezinde bulunan beş eğitim bölgesinden tesadüfî örnekleme yoluyla ikişer ilköğretim okulu, bağlı ilçelerden birer ilköğretim okulu olmak üzere toplam 20 ilköğretim okulu alınmıştır. Örneklemin evreni temsil etmesi açısından yeterli sayıya ulaşabilmek amaciyla il merkezinden üçer okul örnekleme dâhil edilmiştir. Yani yönetici anketleri toplam 30 okuldaki yöneticiye uygulanmıştır. Bu amaçla örneklemden elde edilen 535 öğretmen, 102 yönetici ölçek verileri değerlendirmeye alınmıştır.

\section{Ölçme aracı}

Araştırmada veri toplama aracı olarak "Stratejik Planlamanın Uygulanabilirliğinin Değerlendirilmesi Ölçeği” kullanılmıştır. Ölçme aracı için oluşturulan madde havuzundan Fırat Üniversitesi Eğitim Bilimleri Bölümünden beş ögretim üyesinin uzman görüşü alınarak 38 maddelik stratejik planlamanın uygulanabilirliğinin değerlendirilmesi ölçme aracı oluşturulmuştur. Uzman görüşü aşamasından sonra açımlayıcı faktör analizi yapılarak ölçme aracının yapı geçerliği test edilmiş, ayrıca güvenirlik katsayısı hesaplanmıştır. Ölçme aracında bulunan 38 sorunun Cronbach alfa güvenirlik katsayısı 0,846 olarak bulunmuştur. Ancak geçerlik çalışmalarının sağlanması sürecinde 1, 2, 3, 38 numaralı maddeler çıkarılmış ve 34 maddelik halinin Cronbach alfa güvenirlik katsayısı 0,935 olarak hesaplanmıştır. Yapı geçerliğinin ön şartı olan ölçeğin KMO (Kaiser-Meyer-Olkin) ve Barlett testleri açısından uygun olup olmağı test edilmiştir. Yapılan analiz sonucunda ölçeğin KMO değeri 0,936 ve Barlett küresellik testi değeri 0,05 den küçük bulunmuştur. Buna göre söz konusu ölçeğin yapı geçerliğinin test edilebileceğine karar verilmiştir. Açımlayıcı faktör analizi sonucunda ölçeğin beş faktörlü olduğu belirlenmiştir. Beş faktörlü yapıyı ölçen toplam varyansın \%62,81 olduğu görülmüştür. Bu faktörler şunlardır: "stratejik planın okula kazandırdıkları", "stratejik planlamanın sınırlılıkları", "stratejik planlamanın teknolojik boyutu", "stratejik planın hazırlanma süreci" ve "stratejik planlamada dış kaynak desteği" dir. Araştırmada kullanılan ölçeğe yönelik görüşler çok olumludan çok olumsuza doğru sıralanmaktadır. Buna göre; ("5", puan aralığı: 4,20-5,00) kesinlikle katıllıorum, (“4", puan aralığı: 3,40-4,19) katılıyorum, (“3”, puan aralığı: 2,60 - 3,39) kararsızım, (“2”, puan aralığı: 1,802,59) katılmıyorum, ("1", puan aralığı: 1,00-1,79) kesinlikle katılmıyorum şeklinde bir ölçek 
kullanılmıştır. Elazığ il ve ilçe merkezindeki ilköğretim okullarından tesadüfî (random) örnekleme yöntemi ile seçilen ilköğretim okullarından toplam 11 okulun stratejik plan izleme raporlarına ulaşılmıştır. Gizlilik ilkesinin ihlal edilmemesi amacıyla bu raporları hangi okula ait olduğu saklı tutulmuştur. Raporlar hakkında verilecek her bilgi okul isimleri kullanılmadan A1, A2, A3, A4, A5, A6, A7, A8, A9, A10, A11 şeklinde kodlanarak verilmiştir. Raporların orijinallerine ulaşlıp bir adet fotokopisi alınarak doküman incelemesi yöntemi ile analiz edilmiştir. Yapılan inceleme sonucunda bu raporlarda okullara ait stratejik amaçlar, hedefler, faaliyet/projeler, performans göstergeleri ve amaçların tamamlanıp tamamlanmama durumları hakkında bilgiler elde edilmiştir. Bu bilgiler istatistiksel olarak değerlendirilmiştir.

\section{Verilerin analizi}

Ölçeğin yapı geçerliği için açımlayıcı faktör analizine başvurulmuştur. Ölçek alt boyutları arasındaki ilişkileri saptamak için ise Pearson Korelasyon analizi kullanılmıştır. Niceliksel verilerin karşılaştırılmasında ikili grup durumunda, normal dağılım göstermeyen dağılımlarda gruplar arası karşılaştırmalar Mann Whitney $\mathrm{U}$ testi ile analiz edilmiştir. İkiden fazla grupların karşılaştırılmasında ise dağılımın homojen olmadığı durumlarda Kruskal Wallis H testi ve anlamlı fark tespit edildiğinde bu farkın hangi gruplar arasında olduğunun belirlenmesinde yine Mann Whitney U test kullanılmıştır.

Tablo $\mid$

Stratejik Planlamanın Uygulanabilirliğinin Değerlendirilmesi Ölçeğine Ait Faktör Analizi Sonuçları

\begin{tabular}{|l|l|l|l|}
\hline Boyutlar & Madde & Varyans & Cronbach's Alpha \\
\hline Stratejik planın okula kazandırdıkları & $\begin{array}{l}18,16,19,17,21,15,20,14, \\
23,22\end{array}$ & 18,293 & 0,938 \\
\hline Stratejik planlamanın sinırlılıkları & $34,36,35,33,37,31,30,32$ & 15,218 & 0,911 \\
\hline Stratejik planlamanın teknolojik boyutu & $25,26,27,24,29,28$ & 12,518 & 0,910 \\
\hline Stratejik planın hazırlanma süreci & $7,13,8,4,12,5$ & 10,427 & 0,791 \\
\hline Stratejik planlamada dış kaynak desteği & $9,11,10,6$ & 6,353 & 0,643 \\
\hline
\end{tabular}

Verilerin normal dağılım gösterip göstermediğini test etmek amacıyla Kolmogorov Smirnov testi uygulanmış ve öğretmen ve yöneticilerin görüşlerinin normal dağılıma sahip olmadığg görülmüştür.

\section{Bulgular}

$\mathrm{Bu}$ bölümde, araştırma probleminin çözümü için, araştırmaya katılan öğretmen ve yöneticilerden ölçekler yoluyla toplanan verilerin analizi sonucunda elde edilen bulgular yer almaktadır. Elde edilen bulgulara dayalı olarak açıklama ve yorumlar yapılmıştır. 
Tablo 2

Öğretmen ve Yöneticilerin Demografik Özelliklerine Illişkin Bulgular

\begin{tabular}{|l|c|c|}
\hline Öğretmenlerin branşı & $f$ & $(\%)$ \\
\hline Fen bilimleri & 87 & 16,3 \\
\hline Sosyal bilimleri & 399 & 74,6 \\
\hline Yetenek dersleri & 49 & 9,2 \\
\hline Öğretmenlerin eğitim durumu & $f$ & $(\%)$ \\
\hline Eğitim enstitüsü & 26 & 4,9 \\
\hline Önlisans & 25 & 4,7 \\
\hline Lisans & 453 & 84,7 \\
\hline Yüksek lisans & 30 & 5,6 \\
\hline Doktora & 1 & 0,2 \\
\hline Öğretmenlerin S.P. ile ilgili eğitim alma durumu & $f$ & $(\%)$ \\
\hline Evet & 78 & 14,6 \\
\hline Hayır & 457 & $(\%, 4$ \\
\hline Yöneticilerin branşı & $f$ & 7,8 \\
\hline Fen bilimleri & 8 & 90,2 \\
\hline Sosyal bilimler & 92 & 2,0 \\
\hline Yetenek dersleri & 2 & $(\%)$ \\
\hline Yöneticilerin eğitim durumu & $f$ & 10,8 \\
\hline Önlisans & 11 & 63,7 \\
\hline Lisans & 65 & 7,8 \\
\hline Yüksek lisans & 8 & 17,6 \\
\hline Eğitim enstitüsü & 18 & $(\%)$ \\
\hline Yöneticilerin görevi & $f$ & 29,4 \\
\hline Müdür & 30 & 70,6 \\
\hline Müdür yardımcısı & 72 & $(\%)$ \\
\hline Yöneticilerin S.P. ile ilgili eğitim alma & $f$ & 28,6 \\
\hline Evet & 73 & \\
\hline Hayır & & \\
\hline & 29 & \\
\hline
\end{tabular}

Tablo 2'ye göre, öğretmenlerin 87'si (\%16,3) Fen Bilimleri, 399’u (\%74,6) Sosyal Bilimler, 49'u $(\% 9,2)$ Yetenek Dersleri branşındandır. Eğitim durumu değişkenine göre ise öğretmenlerin 26 ’sı (\%4,9) eğitim enstitüsü, 25’i (\%4,7) önlisans, 453’ü (\%84,7) lisans, 30’u (\%5,6) yüksek lisans, 1’i $(\% 0,2)$ doktora mezunudur. Öğretmenlerin 78’i $(\% 14,6)$ stratejik planlama ile ilgili herhangi bir eğitim almış iken, 457’si $(\% 85,4)$ stratejik planlamaya yönelik herhangi bir eğitim almadı̆̆ını belirtmişlerdir. Tablo 2'ye göre araştırmaya katılan yöneticilerin 8’i $(\% 7,8)$ Fen Bilimleri, 92'si $(\% 90,2)$ Sosyal Bilimler, 2’si (\%2,0) Yetenek Dersleri branşındadır. Yöneticilerin 18’i $(\% 17,6)$ eğitim enstitüsü, 11’i (\%10,8) önlisans, 65’i (\%63,7) lisans, 8’i $(\% 7,8)$ yüksek lisans mezunudur. Tabloya göre yöneticilerin görev dağılımları incelendiğinde 30’u $(\% 29,4)$ müdür, 72’si $(\% 70,6)$ müdür yardımcısıdır. Stratejik planlama ile ilgili eğitim alıp almadıklarına ilişkin soruya yöneticilerin 29’u $(\% 28,4)$ evet, 73’ü $(\% 71,6)$ hayır yanıtını vermişlerdir. 
Tablo 3

Ölçek Boyutlarının Öğretmen ve Yöneticilere Göre Dağııımı

\begin{tabular}{|c|c|c|c|c|c|c|}
\hline \multirow[t]{2}{*}{ Boyutlar } & \multicolumn{2}{|c|}{ Öğretmen } & \multicolumn{2}{|c|}{ Yönetici } & \multirow[b]{2}{*}{$\mathrm{U}$} & \multirow[b]{2}{*}{$\mathrm{p}$} \\
\hline & $\overline{\mathrm{X}}$ & SS & $\overline{\mathrm{X}}$ & SS & & \\
\hline Stratejik planın okula kazandırdıkları & 4,13 & 0,67 & 4,14 & 0,79 & 25451,500 & 0,280 \\
\hline Stratejik planlamanın sınırlılıkları & 3,53 & 0,87 & 3,89 & 0,79 & 20192,000 & 0,000 \\
\hline Stratejik planlamanın teknolojik boyutu & 3,98 & 0,70 & 3,96 & 0,79 & 26436,000 & 0,616 \\
\hline Stratejik planın hazırlanma süreci & 4,32 & 0,58 & 4,11 & 0,55 & 20530,500 & 0,000 \\
\hline Stratejik planlamada dış kaynak desteği & 3,84 & 0,71 & 4,05 & 0,64 & 22521,500 & 0,005 \\
\hline
\end{tabular}

Tablo 4 incelendiğinde stratejik planın okula kazandırdıkları boyutu ile stratejik planlamanın teknolojik boyutuna ilişkin görüşlere ait ortalamaların öğretmen ve yöneticilerin görüşlerine göre anlamlı bir farklılık göstermediği görülmektedir. Diğer boyutlarda ise anlamlı farklılık görülmüştür. Stratejik planlamada dış kaynak desteği boyutuna ilişkin görüşlere ait ortalamaların grup değişkenine göre anlamlı bir farklılık gösterip göstermediğini belirlemek amacıyla yapılan Mann Whitney-U sonucunda grup ortalamaları arasındaki fark istatistiksel açıdan anlamlı bulunmuştur (MWU=22521,50; $\mathrm{p}=0,005<0,05)$.Yöneticilerin Stratejik Planlamada diş kaynak desteği boyutuna ilişkin görüşlerinin düzeyi $(\overline{\mathrm{X}}=4,05)$, öğretmenlerin görüşlerinin düzeyinden $(\overline{\mathrm{X}}=3,84)$ daha yüksektir. Stratejik Planın Hazırlanma Süreci boyutuna ilişkin görüşlere ait ortalamaların grup değişkenine göre anlamlı bir farklılık gösterip göstermediğini belirlemek amaciyla yapılan Mann Whitney-U sonucunda grup ortalamaları arasındaki fark istatistiksel açıdan anlamlı bulunmuştur (MWU=20530,50; $p=0,000<0,05)$. Öğretmenlerin Stratejik Planın Hazırlanma Süreci boyutuna ilişkin görüşlerinin düzeyi $(\overline{\mathrm{X}}=4,32)$, yöneticilerin görüşlerinin düzeyinden $(\overline{\mathrm{X}}=4,11)$ daha yüksektir. Stratejik Planlamanın Sınırlılıkları boyutuna ilişkin görüşlere ait ortalamaların grup değişkenine göre anlamlı bir farklılık gösterip göstermediğini belirlemek amaciyla yapılan Mann Whitney-U sonucunda grup ortalamaları arasındaki fark istatistiksel açıdan anlamlı bulunmuştur (MWU $=20192,00 ; \mathrm{p}=0,000<0,05)$. Yöneticilerin Stratejik Planlamanın Sınırlılıkları boyutuna ilişkin görüşlerinin düzeyi $(\overline{\mathbf{X}}=3,89)$, öğretmenlerin görüşlerinin düzeyinden $(\overline{\mathrm{X}}=3,53)$ daha yüksektir.

Aşağıdaki radar grafiğinde stratejik planlamanın uygulanabilirliği ölçeğindeki boyutların öğretmenlerin ve yöneticilerin görüşlerinin düzeyine göre ortaya çıkan dağılım verilmiştir. 


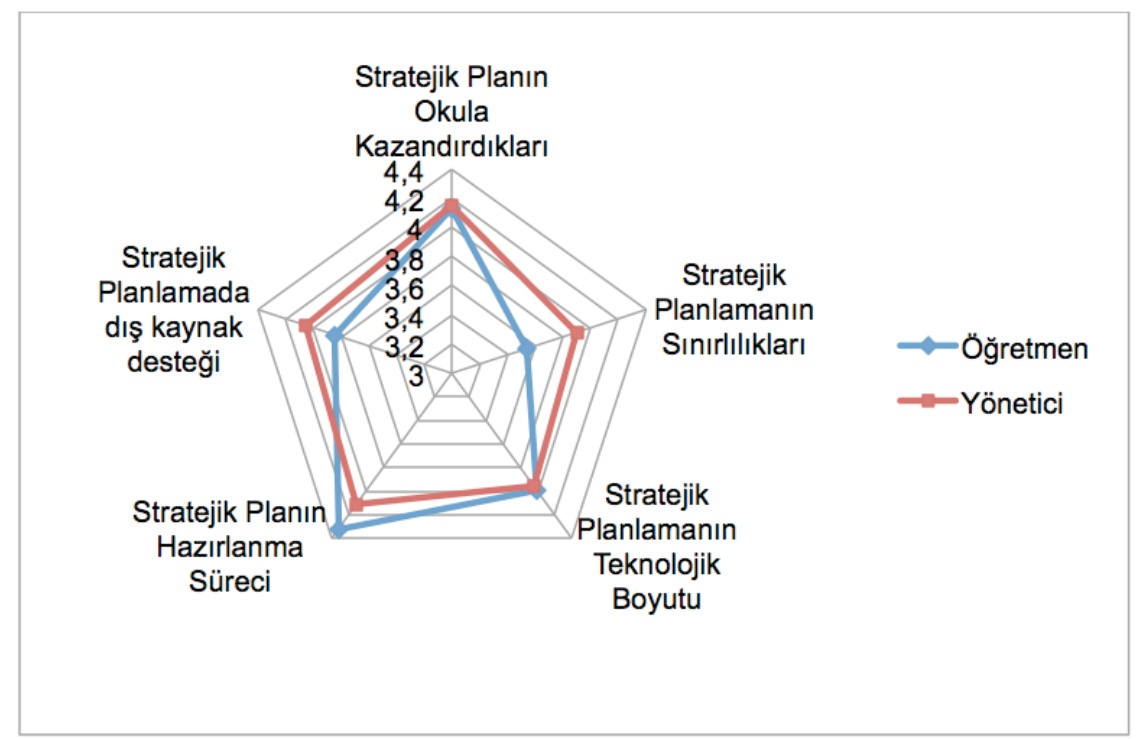

Şekil I. Ölçek boyutlarına göre yönetici ve öğretmenlerin görüşlerinin düzeyi

Tablo 5

Öğretmenlerin Görüşlerine Göre Ölçek Boyutlarının Korelasyon Analizi.

\begin{tabular}{|c|c|c|c|c|c|c|}
\hline & & $\begin{array}{l}\text { Stratejik } \\
\text { planın okula } \\
\text { kazandırdıkları }\end{array}$ & $\begin{array}{l}\text { Stratejik } \\
\text { planlamanın } \\
\text { sinırlılıkları }\end{array}$ & $\begin{array}{l}\text { Stratejik } \\
\text { planlamanın } \\
\text { teknolojik } \\
\text { boyutu }\end{array}$ & $\begin{array}{l}\text { Stratejik } \\
\text { planın } \\
\text { hazırlanma } \\
\text { süreci }\end{array}$ & $\begin{array}{l}\text { Stratejik } \\
\text { planlamada } \\
\text { diş kaynak } \\
\text { desteği }\end{array}$ \\
\hline \multirow{2}{*}{$\begin{array}{l}\text { Stratejik } \\
\text { planın okula } \\
\text { kazandırdıkları }\end{array}$} & $\mathrm{r}$ & 1,000 & 0,389 & 0,730 & 0,518 & 0,423 \\
\hline & $\mathrm{p}$ & 0,000 & 0,000 & 0,000 & 0,000 & 0,000 \\
\hline \multirow{2}{*}{$\begin{array}{l}\text { Stratejik } \\
\text { planlamanın } \\
\text { sinırlılıkları }\end{array}$} & $\mathrm{r}$ & 0,389 & 1,000 & 0,307 & 0,258 & 0,190 \\
\hline & $\mathrm{p}$ & 0,000 & 0,000 & 0,000 & 0,000 & 0,000 \\
\hline \multirow{2}{*}{$\begin{array}{l}\text { Stratejik } \\
\text { planlamanın } \\
\text { teknolojik boyutu }\end{array}$} & $\mathrm{r}$ & 0,730 & 0,307 & 1,000 & 0,406 & 0,373 \\
\hline & $\mathrm{p}$ & 0,000 & 0,000 & 0,000 & 0,000 & 0,000 \\
\hline \multirow{2}{*}{$\begin{array}{l}\text { Stratejik planın } \\
\text { hazırlanma süreci }\end{array}$} & $\mathrm{r}$ & 0,518 & 0,258 & 0,406 & 1,000 & 0,489 \\
\hline & $\mathrm{p}$ & 0,000 & 0,000 & 0,000 & 0,000 & 0,000 \\
\hline \multirow{2}{*}{$\begin{array}{l}\text { Stratejik } \\
\text { planlamada dış } \\
\text { kaynak desteği }\end{array}$} & $\mathrm{r}$ & 0,423 & 0,190 & 0,373 & 0,489 & 1,000 \\
\hline & $\mathrm{p}$ & 0,000 & 0,000 & 0,000 & 0,000 & 0,000 \\
\hline
\end{tabular}


Öğretmenlere ait ölçeğin tüm boyutları arasındaki ilişkiyi belirlemek üzere yapılan korelasyon analizi sonucunda, Tablo 5’te de görüldüğü gibi pozitif yönde anlamlı ilişki bulunmuştur. Buna göre öğretmenler için boyut fark etmeksizin, boyut ortalaması arttıkça diğer boyutun ortalaması da artmaktadır.

Tablo 6

Yöneticilerin Görüşlerine Göre Ölçek Boyutlarının Korelasyon Analizi

\begin{tabular}{|l|c|c|c|c|c|c|}
\hline & & $\begin{array}{l}\text { Stratejik } \\
\text { planın okula } \\
\text { kazandırdıkları }\end{array}$ & $\begin{array}{l}\text { Stratejik } \\
\text { planlamanın } \\
\text { sinırlılıları }\end{array}$ & $\begin{array}{l}\text { Stratejik } \\
\text { planlamanın } \\
\text { teknolojik } \\
\text { boyutu }\end{array}$ & $\begin{array}{l}\text { Stratejik planın } \\
\text { hazırlanma } \\
\text { süreci }\end{array}$ & $\begin{array}{l}\text { Stratejik } \\
\text { planlamada dış } \\
\text { kaynak desteği }\end{array}$ \\
\hline $\begin{array}{l}\text { Stratejik } \\
\text { planın okula } \\
\text { kazandırdıkları }\end{array}$ & $\mathrm{r}$ & 1,000 & 0,414 & 0,764 & 0,414 & 0,486 \\
\cline { 2 - 7 } & $\mathrm{p}$ & 0,000 & 0,000 & 0,000 & 0,000 & 0,000 \\
\hline $\begin{array}{l}\text { Stratejik } \\
\text { planlamanın } \\
\text { sınırlılıları }\end{array}$ & $\mathrm{r}$ & 0,414 & 1,000 & 0,344 & 0,052 & 0,179 \\
\cline { 2 - 7 } $\begin{array}{l}\text { Stratejik } \\
\text { planlamanın } \\
\text { teknolojik } \\
\text { boyutu }\end{array}$ & $\mathrm{p}$ & 0,000 & 0,000 & 0,000 & 0,602 & 0,071 \\
\cline { 2 - 7 } & $\mathrm{p}$ & 0,000 & 0,000 & 0,000 & 0,435 \\
\hline $\begin{array}{l}\text { Stratejik planın } \\
\text { hazırlanma } \\
\text { süreci }\end{array}$ & $\mathrm{r}$ & 0,414 & 0,052 & 0,442 & 1,000 & 0,000 \\
\cline { 2 - 7 } & $\mathrm{p}$ & 0,000 & 0,602 & 0,000 & 0,000 & 0,000 \\
\hline $\begin{array}{l}\text { Stratejik } \\
\text { planlamada dış } \\
\text { kaynak desteği }\end{array}$ & $\mathrm{p}$ & 0,000 & 0,071 & 0,000 & 0,000 & 0,000 \\
\hline
\end{tabular}

Tablo 6 incelendiğinde yapılan korelasyon analizi sonucunda yöneticilerin boyutlar arası ilişkisi incelendiğinde üç boyut arasında anlamlı ve pozitif yön de bir ilişki olduğu görülmektedir. "Stratejik planın hazırlanma süreci" boyutu ile "stratejik planlamanın sinırlılıkları" boyutu arasındaki ilişkiyi belirlemek üzere yapılan korelasyon analizi sonucunda, puanlar arasında istatistiksel açıdan anlamlı ilişki bulunmamıştır ( $r=0,052 ; p=0,602>0,05)$. "Stratejik planlamada dış kaynak desteği” boyutu ile "stratejik planlamanın sınırlılıkları” boyutu arasındaki ilişkiyi belirlemek üzere yapılan korelasyon analizi sonucunda, puanlar arasında istatistiksel açıdan anlamlı ilişki bulunmamıştır ( $r=0,179 ; \mathrm{p}=0,071>0,05)$. 
Tablo 7

Öğretmenlerin Branş Değişkenine Göre Görüşlerine Ilişkin İstatistikler

\begin{tabular}{|c|c|c|c|c|c|c|}
\hline & & $\mathbf{N}$ & $\overline{\mathrm{X}}$ & SS & KW & $\mathbf{p}$ \\
\hline \multirow{3}{*}{$\begin{array}{l}\text { Stratejik planın okula } \\
\text { kazandırdıkları }\end{array}$} & Fen bilimleri & 87 & 3,99 & 0,73 & \multirow{3}{*}{4,352} & \multirow{3}{*}{0,114} \\
\hline & Sosyal bilimleri & 399 & 4,16 & 0,65 & & \\
\hline & $\begin{array}{l}\text { Yetenek } \\
\text { dersleri }\end{array}$ & 49 & 4,11 & 0,67 & & \\
\hline \multirow{3}{*}{$\begin{array}{l}\text { Stratejik planlamanın } \\
\text { sinırlılıkları }\end{array}$} & Fen bilimleri & 87 & 3,43 & 0,89 & \multirow{3}{*}{3,828} & \multirow{3}{*}{0,147} \\
\hline & Sosyal bilimleri & 399 & 3,57 & 0,87 & & \\
\hline & $\begin{array}{l}\text { Yetenek } \\
\text { dersleri }\end{array}$ & 49 & 3,40 & 0,87 & & \\
\hline \multirow{3}{*}{$\begin{array}{l}\text { Stratejik planlamanın } \\
\text { teknolojik boyutu }\end{array}$} & Fen bilimleri & 87 & 3,83 & 0,70 & \multirow{3}{*}{5,475} & \multirow{3}{*}{0,065} \\
\hline & Sosyal bilimleri & 399 & 4,01 & 0,70 & & \\
\hline & $\begin{array}{l}\text { Yetenek } \\
\text { dersleri }\end{array}$ & 49 & 4,06 & 0,67 & & \\
\hline \multirow{3}{*}{$\begin{array}{l}\text { Stratejik planın } \\
\text { hazırlanma süreci }\end{array}$} & Fen bilimleri & 87 & 4,28 & 0,57 & \multirow{3}{*}{1,004} & \multirow{3}{*}{0,605} \\
\hline & Sosyal bilimleri & 399 & 4,33 & 0,59 & & \\
\hline & $\begin{array}{l}\text { Yetenek } \\
\text { dersleri }\end{array}$ & 49 & 4,34 & 0,56 & & \\
\hline \multirow{3}{*}{$\begin{array}{l}\text { Stratejik planlamada } \\
\text { dış kaynak desteği }\end{array}$} & Fen bilimleri & 87 & 3,64 & 0,82 & \multirow[t]{3}{*}{6,726} & \multirow[t]{3}{*}{0,035} \\
\hline & Sosyal bilimleri & 399 & 3,86 & 0,70 & & \\
\hline & $\begin{array}{l}\text { Yetenek } \\
\text { dersleri }\end{array}$ & 49 & 3,99 & 0,51 & & \\
\hline
\end{tabular}

Öğretmenlerin görüşlerinin branş değişkenine göre tüm boyutlar açısından anlamlı bir farklılık gösterip göstermediğini belirlemek amacıyla yapılan Kruskal Wallis H-Testi sonuçlarına göre; ilk dört boyutta grup ortalamaları arasındaki fark anlamlı bulunmamıştır. "Stratejik planlamada dış kaynak desteği” boyutunda ise ortalamalar arasında anlamlı fark bulunmuştur $(\mathrm{KW}=6,726 ; \mathrm{p}=0,035<0,05)$. Bunun üzerine farklılı̆̆ın hangi gruptan kaynaklandığını belirlemek üzere Mann Whitney U testi uygulanmıştır. Buna göre; Sosyal Bilimler branşındaki öğretmenler $(\mathrm{U}=14896,500 ; \mathrm{p}=0,037<0,05)$ ile yetenek dersleri branşındaki öğretmenlerin $(\mathrm{U}=1593,500$; $\mathrm{p}=0,014<0,05)$ "stratejik planlamada dış kaynak desteği” boyutuna ilişkin görüşleri, Fen Bilimleri branşındaki öğretmenlerin görüşlerinden daha yüksek bulunmuştur. 
Tablo 8

Öğretmenlerin Boyutlar Temelinde Eğitim Durumu Değişkenine Göre Görüşlerine Illişkin Veriler

\begin{tabular}{|c|c|c|c|c|c|c|}
\hline & Eğitim Durumu & $\mathbf{N}$ & $\overline{\mathbf{X}}$ & SS & $\mathrm{Z}$ & $\mathbf{p}$ \\
\hline \multirow{4}{*}{$\begin{array}{l}\text { Stratejik planın okula } \\
\text { kazandırdıkları }\end{array}$} & Eğitim enstitüsü & 26 & 4,13 & 0,71 & \multirow{4}{*}{1,184} & \multirow{4}{*}{0,757} \\
\hline & Önlisans & 25 & 4,06 & 0,92 & & \\
\hline & Lisans & 453 & 4,12 & 0,66 & & \\
\hline & Y. lisans ve doktora & 31 & 4,27 & 0,54 & & \\
\hline \multirow{4}{*}{$\begin{array}{l}\text { Stratejik planlamanın } \\
\text { sinırlılıkları }\end{array}$} & Eğitim enstitüsü & 26 & 3,59 & 0,88 & \multirow{4}{*}{5,894} & \multirow{4}{*}{0,117} \\
\hline & Önlisans & 25 & 3,07 & 1,19 & & \\
\hline & Lisans & 453 & 3,53 & 0,86 & & \\
\hline & Y. lisans ve doktora & 31 & 3,79 & 0,66 & & \\
\hline \multirow{4}{*}{$\begin{array}{l}\text { Stratejik planlamanın } \\
\text { teknolojik boyutu }\end{array}$} & Eğitim enstitüsü & 26 & 4,09 & 0,64 & \multirow{4}{*}{1,464} & \multirow{4}{*}{0,691} \\
\hline & Önlisans & 25 & 3,96 & 0,88 & & \\
\hline & Lisans & 453 & 3,98 & 0,70 & & \\
\hline & Y. lisans ve doktora & 31 & 3,92 & 0,62 & & \\
\hline \multirow{4}{*}{$\begin{array}{l}\text { Stratejik planın } \\
\text { hazırlanma süreci }\end{array}$} & Eğitim enstitüsü & 26 & 4,09 & 0,63 & \multirow{4}{*}{8,610} & \multirow{4}{*}{0,035} \\
\hline & Önlisans & 25 & 4,28 & 0,89 & & \\
\hline & Lisans & 453 & 4,33 & 0,56 & & \\
\hline & Y. lisans ve doktora & 31 & 4,51 & 0,45 & & \\
\hline \multirow{4}{*}{$\begin{array}{l}\text { Stratejik planlamada dış } \\
\text { kaynak desteği }\end{array}$} & Eğitim enstitüsü & 26 & 3,92 & 0,71 & \multirow{4}{*}{1,460} & \multirow{4}{*}{0,691} \\
\hline & Önlisans & 25 & 3,89 & 0,93 & & \\
\hline & Lisans & 453 & 3,82 & 0,70 & & \\
\hline & Y. lisans ve doktora & 31 & 3,93 & 0,64 & & \\
\hline
\end{tabular}

Öğretmenlerin stratejik planlamanın uygulanabilirliği ölçeğindeki boyutlara ilişkin görüşlerinin eğitim durumu değişkenine göre anlamlı bir farklılık gösterip göstermediğini belirlemek için yapılan Kruskal Wallis H-Testi’ne göre dört boyutta anlamlı bir farklılığın olmadığ görülmüştür. Ancak, öğretmenlerin Stratejik Planın Hazırlanma Süreci boyutuna ilişkin görüşleri arasında anlamlı bir fark bulunmuştur $(\mathrm{KW}=8,610 ; \mathrm{p}=0,035<0,05)$. Farklılığın hangi gruptan kaynaklandığını belirlemek üzere Mann Whitney $U$ testi uygulanmıştır. Buna göre; eğitim düzeyi lisans olan öğretmenlerin Stratejik Planın Hazırlanma Süreci boyutuna ilişkin görüşleri, eğitim düzeyi eğitim enstitüsü olan öğretmenlerin görüşlerinden daha yüksek bulunmuştur (MWU=4447,500; p=0,034<0,05). Eğitim düzeyi yüksek lisans ve doktora olan öğretmenlerin ise aynı boyuta ilişkin görüşleri, eğitim düzeyi eğitim enstitüsü olan öğretmenlerin görüşlerinden daha yüksek bulunmuştur (MWU=238,500; $\mathrm{p}=0,008<0,05)$. 
Tablo 9

Öğretmenlerin Boyutlar Temelinde Stratejik Planlama Ile Illgili Eğitim Alma Değişkenine Göre Verilerin Dağılımı

\begin{tabular}{|c|c|c|c|c|c|c|}
\hline & & $\mathbf{N}$ & $\overline{\mathrm{X}}$ & SS & $\mathrm{U}$ & $\mathbf{p}$ \\
\hline \multirow{2}{*}{$\begin{array}{l}\text { Stratejik planın okula } \\
\text { kazandırdıkları }\end{array}$} & Evet & 78 & 4,22 & 0,82 & \multirow[t]{2}{*}{14438,500} & \multirow[t]{2}{*}{0,007} \\
\hline & Hayır & 457 & 4,11 & 0,64 & & \\
\hline \multirow{2}{*}{ Stratejik planlamanın sınırlılıkları } & Evet & 78 & 3,42 & 1,13 & \multirow[t]{2}{*}{17356,500} & \multirow[t]{2}{*}{0,711} \\
\hline & Hayır & 457 & 3,55 & 0,82 & & \\
\hline \multirow{2}{*}{$\begin{array}{l}\text { Stratejik planlamanın teknolojik } \\
\text { boyutu }\end{array}$} & Evet & 78 & 4,01 & 0,81 & \multirow[t]{2}{*}{16335,000} & \multirow[t]{2}{*}{0,234} \\
\hline & Hayır & 457 & 3,98 & 0,68 & & \\
\hline \multirow{2}{*}{ Stratejik planın hazırlanma süreci } & Evet & 78 & 4,20 & 0,80 & \multirow[t]{2}{*}{17118,500} & \multirow[t]{2}{*}{0,574} \\
\hline & Hayır & 457 & 4,34 & 0,53 & & \\
\hline \multirow{2}{*}{$\begin{array}{l}\text { Stratejik planlamada dış kaynak } \\
\text { desteği }\end{array}$} & Evet & 78 & 3,88 & 0,84 & \multirow[t]{2}{*}{15970,500} & \multirow[t]{2}{*}{0,139} \\
\hline & Hayır & 457 & 3,83 & 0,69 & & \\
\hline
\end{tabular}

Araştırmaya katılan öğretmenlerin "stratejik planın okula kazandırdıkları” boyutuna ilişkin görüşlerinin, stratejik planlama ile ilgili eğitim alma değişkenine göre anlamlı bir farklılık gösterip göstermediğini belirlemek amacıyla yapılan Mann Whitney-U testi sonucunda grup ortalamaları arasındaki fark istatistiksel açıdan anlamlı bulunmuştur (Mann Whitney-U=14438,50; $\mathrm{p}=0,007<0,05)$. Stratejik planlama ile ilgili eğitim almış olan öğretmenlerin "stratejik planın okula kazandırdıkları” boyutuna ilişkin görüşleri $(\overline{\mathrm{X}}=4,22)$, stratejik planlama ile ilgili eğitim almayan öğretmenlerin "stratejik planın okula kazandırdıkları" boyutuna ilişkin görüşlerinden $(\overline{\mathrm{X}}=4,11)$ daha yüksek bulunmuştur. Araştırmaya katılan öğretmenlerin stratejik planlamanın uygulanabilirliği ölçeğinde ki diğer boyutlara ilişkin görüşlerinin "stratejik planlama ile ilgili eğitim alma” değişkenine göre anlamlı bir farklılık gösterip göstermediği Kruskal Wallis $\mathrm{H}$-Testi’ne göre incelenmiştir. Kruskal Wallis H-Testi’ne göre dört boyutta anlamlı bir farklılığın olmadığı görülmüştür. 
Tablo 10

Yöneticilerin Boyutlar Temelinde Branş Değişkenine Göre Verilerin Dağılımı

\begin{tabular}{|c|c|c|c|c|c|c|}
\hline & & $\mathbf{N}$ & $\overline{\mathrm{X}}$ & SS & $\mathrm{Z}$ & $\mathbf{p}$ \\
\hline \multirow{3}{*}{ Stratejik planın okula kazandırdıkları } & Fen bilimleri & 8 & 4,25 & 1,00 & \multirow{3}{*}{2,994} & \multirow{3}{*}{0,224} \\
\hline & Sosyal bilimler & 92 & 4,12 & 0,78 & & \\
\hline & Özel yetenek & 2 & 4,85 & 0,21 & & \\
\hline \multirow{3}{*}{ Stratejik planlamanın sınırlılıkları } & Fen bilimleri & 8 & 4,14 & 0,66 & \multirow{3}{*}{0,910} & \multirow{3}{*}{0,634} \\
\hline & Sosyal bilimler & 92 & 3,88 & 0,80 & & \\
\hline & Özel yetenek & 2 & 3,68 & 0,44 & & \\
\hline \multirow{3}{*}{ Stratejik planlamanın teknolojik boyutu } & Fen bilimleri & 8 & 4,04 & 1,04 & \multirow{3}{*}{0,469} & \multirow{3}{*}{0,791} \\
\hline & Sosyal bilimler & 92 & 3,94 & 0,78 & & \\
\hline & Özel yetenek & 2 & 4,16 & 0,00 & & \\
\hline \multirow{3}{*}{ Stratejik planın hazırlanma süreci } & Fen bilimleri & 8 & 4,31 & 0,48 & \multirow{3}{*}{3,729} & \multirow{3}{*}{0,155} \\
\hline & Sosyal bilimler & 92 & 4,10 & 0,56 & & \\
\hline & Özel yetenek & 2 & 3,66 & 0,00 & & \\
\hline \multirow{3}{*}{ Stratejik planlamada dış kaynak desteği } & Fen bilimleri & 8 & 4,18 & 0,67 & \multirow{3}{*}{0,433} & \multirow{3}{*}{0,805} \\
\hline & Sosyal bilimler & 92 & 4,04 & 0,65 & & \\
\hline & Özel yetenek & 2 & 4,125 & & & \\
\hline
\end{tabular}

Araştırmaya katılan yöneticilerin stratejik planlamanın uygulanabilirliği ölçeğinde ki tüm boyutlara ilişkin görüşleri "branş” değişkenine göre anlamlı bir farklılık gösterip göstermediği Kruskal Wallis H-Testi’ne göre incelenmiştir. Tabloda verilen değerlerde de anlaşıldığı gibi Kruskal Wallis H-Testi’ne göre tüm boyutlarda branş değişkenine göre anlamlı bir farklılığın olmadığı görülmüştür. 
Tablo I I

Yöneticilerin Boyutlar Temelinde Eğitim Durumu Değişkenine Göre Verilerin Dağılımı

\begin{tabular}{|c|c|c|c|c|c|c|}
\hline & Eğitim Durumu & $\mathbf{N}$ & $\overline{\mathbf{X}}$ & SS & $\mathbf{Z}$ & $\mathbf{p}$ \\
\hline \multirow{4}{*}{ Stratejik planın okula kazandırdıkları } & Eğitim enstitüsü & 18 & 4,15 & 0,45 & \multirow{4}{*}{5,826} & \multirow{4}{*}{0,120} \\
\hline & Önlisans & 11 & 4,21 & 0,61 & & \\
\hline & Lisans & 65 & 4,06 & 0,90 & & \\
\hline & Yüksek lisans & 8 & 4,70 & 0,43 & & \\
\hline \multirow{4}{*}{ Stratejik planlamanın sınırlılıkları } & Eğitim enstitüsü & 18 & 3,63 & 0,86 & \multirow{4}{*}{5,311} & \multirow{4}{*}{0,150} \\
\hline & Önlisans & 11 & 3,80 & 0,74 & & \\
\hline & Lisans & 65 & 3,93 & 0,76 & & \\
\hline & Yüksek lisans & 8 & 4,31 & 0,85 & & \\
\hline \multirow{4}{*}{ Stratejik planlamanın teknolojik boyutu } & Eğitim enstitüsü & 18 & 4,00 & 0,48 & \multirow{4}{*}{5,103} & \multirow{4}{*}{0,164} \\
\hline & Önlisans & 11 & 3,78 & 0,70 & & \\
\hline & Lisans & 65 & 3,91 & 0,88 & & \\
\hline & Yüksek lisans & 8 & 4,50 & 0,44 & & \\
\hline \multirow{4}{*}{ Stratejik planın hazırlanma süreci } & Eğitim enstitüsü & 18 & 3,99 & 0,66 & \multirow{4}{*}{1,904} & \multirow{4}{*}{0,593} \\
\hline & Önlisans & 11 & 4,25 & 0,32 & & \\
\hline & Lisans & 65 & 4,09 & 0,58 & & \\
\hline & Yüksek lisans & 8 & 4,31 & 0,22 & & \\
\hline \multirow{4}{*}{ Stratejik planlamada dış kaynak desteği } & Eğitim enstitüsü & 18 & 3,68 & 0,72 & \multirow{4}{*}{7,157} & \multirow{4}{*}{0,057} \\
\hline & Önlisans & 11 & 4,06 & 0,66 & & \\
\hline & Lisans & 65 & 4,11 & 0,59 & & \\
\hline & Yüksek lisans & 8 & 4,43 & 0,57 & & \\
\hline
\end{tabular}

Araştırmaya katılan yöneticilerin stratejik planlamanın uygulanabilirliği ölçeğinde ki tüm boyutlara ilişkin görüşleri "eğitim durumu” değişkenine göre anlamlı bir farklılık gösterip göstermediği Kruskal Wallis H-Testi’ne göre incelenmiştir. Tabloda verilen değerlerde de anlaşıldığ gibi Kruskal Wallis H-Testi’ne göre tüm boyutlarda eğitim düzeyi değişkenine göre anlamlı bir farklılı̆̆ın olmadığı görülmüştür.

Tablo 12

Yöneticilerin Boyutlar Temelinde Görev Değişkenine Göre Verilerin Dağılımı

\begin{tabular}{|l|l|l|l|l|c|c|}
\hline & Görev & N & $\overline{\mathbf{X}}$ & SS & U & p \\
\hline \multirow{2}{*}{ Stratejik planın okula kazandırdıkları } & Müdür & 30 & 4,16 & 0,86 & 1040,000 & 0,768 \\
\cline { 2 - 5 } & Müdür yardımcısı & 72 & 4,13 & 0,77 & & \\
\hline \multirow{2}{*}{ Stratejik planlamanın sınırlılıkları } & Müdür & 30 & 4,00 & 0,79 & 925,500 & 0,255 \\
\cline { 2 - 5 } & Müdür yardımcısı & 72 & 3,85 & 0,79 & & \\
\hline \multirow{2}{*}{ Stratejik planlamanın teknolojik boyutu } & Müdür & 30 & 3,86 & 0,94 & \multirow{2}{*}{1033,500} & \multirow{2}{*}{0,732} \\
\cline { 2 - 5 } & Müdür yardımcısı & 72 & 4,00 & 0,72 & & \\
\hline Stratejik planın hazırlanma süreci & Müdür & 30 & 4,28 & 0,44 & \multirow{2}{*}{813,500} & \multirow{2}{*}{0,049} \\
\cline { 2 - 5 } & Müdür yardımcısı & 72 & 4,03 & 0,58 & & \\
\hline Stratejik planlamada dış kaynak desteği & Müdür & 30 & 4,07 & 0,62 & 1069,500 & 0,938 \\
\cline { 2 - 4 } & Müdür yardımcısı & 72 & 4,05 & 0,66 & & \\
\hline
\end{tabular}


Araştırmaya katılan yöneticilerin stratejik planlamanın uygulanabilirliği ölçeğinde ki tüm boyutlara ilişkin görüşleri "görev" değişkenine göre anlamlı bir farklılık gösterip göstermediği Mann Whitney-U Testi’ne göre incelenmiştir. Mann Whitney-U Testi’ne göre tüm boyutlarda görev dağılımı değişkenine göre anlamlı bir farklılığın olmadığı görülmüşsür.

Tablo 13

Yöneticilerin Boyutlar Temelinde Stratejik Planlama Ile Illgili Eğitim Alma Değişkenine Göre Verilerin Dağılımı

\begin{tabular}{|l|l|c|c|c|c|c|}
\hline Eğitim Alma & & $\mathbf{N}$ & $\overline{\mathbf{X}}$ & $\mathbf{S S}$ & $\mathbf{U}$ & $\mathbf{p}$ \\
\hline \multirow{2}{*}{ Stratejik planın okula kazandırdıkları } & Evet & 29 & 4,31 & 0,79 & 813,500 & 0,068 \\
\cline { 2 - 5 } & Hayır & 73 & 4,07 & 0,79 & & \\
\hline \multirow{2}{*}{ Stratejik planlamanın sınırlılıkları } & Evet & 29 & 3,92 & 0,90 & 976,500 & 0,542 \\
\cline { 2 - 5 } & Hayır & 73 & 3,88 & 0,75 & & \\
\hline \multirow{2}{*}{ Stratejik planlamanın teknolojik boyutu } & Evet & 29 & 4,14 & 0,71 & \multirow{2}{*}{882,500} & 0,190 \\
\cline { 2 - 5 } & Hayır & 73 & 3,88 & 0,81 & & \\
\hline \multirow{2}{*}{ Stratejik planın hazırlanma süreci } & Evet & 29 & 4,27 & 0,47 & 821,500 & \multirow{2}{*}{0,077} \\
\cline { 2 - 5 } & Hayır & 73 & 4,04 & 0,57 & & \\
\hline Stratejik planlamada dış kaynak desteği & Evet & 29 & 4,18 & 0,63 & 901,000 & 0,239 \\
\cline { 2 - 5 } & Hayır & 73 & 4,01 & 0,65 & & \\
\hline
\end{tabular}

Araştırmaya katılan yöneticilerin stratejik planlamanın uygulanabilirliği ölçeğindeki tüm boyutlara ilişkin görüşleri "stratejik planlama ile ilgili eğitim alma” değişkenine göre anlamlı bir farklılık gösterip göstermediği Mann Whitney-U Testi’ne göre incelenmiştir. Mann Whitney-U Testi’ne göre tüm boyutlarda stratejik planlama ile ilgili eğitim alma değişkenine göre anlamlı bir farklılı̆̆ın olmadı̆̆ görülmüştür.

\section{Tartışma}

Öğretmenlerin 78’i $(\% 14,6)$ stratejik planlama ile ilgili bir eğitim alırken, 457'si $(\% 85,4)$ herhangi bir eğitim almamıştır. Yöneticilerin 29’u (\%8,4) stratejik planlama ile ilgili eğitim alırken, 73 'ü $(\% 71,6)$ almamıştır. Yöneticilerin stratejik planlamada dış kaynak desteği boyutuna ilişkin görüşlerinin düzeyi, öğretmenlerin görüşlerinin düzeyinden daha yüksektir. Öğretmenlerin stratejik planın hazırlanma süreci boyutuna ilişkin görüşlerinin düzeyi, yöneticilerin görüşlerinin düzeyinden daha yüksektir. Yöneticilerin stratejik planlamanın sınırlılıkları boyutuna ilişkin görüşlerinin düzeyi, öğretmenlerin görüşlerinin düzeyinden daha yüksektir. Sosyal Bilimler branşındaki öğretmenlerin stratejik planlamada dış kaynak desteği boyutuna ilişkin görüşleri, Fen Bilimleri branşında ki öğretmenlerin görüşlerinden daha yüksektir. Eğitim düzeyi lisans olan öğretmenlerin stratejik planın hazırlanma süreci boyutuna ilişkin görüşleri, eğitim düzeyi 
eğitim enstitüsü olan öğretmenlerin görüşlerinden daha yüksektir. Eğitim düzeyi yüksek lisans ve doktora olan öğretmenlerin ise aynı boyuta ilişkin görüşleri, eğitim düzeyi eğitim enstitüsü olan öğretmenlerin görüşlerinden daha yüksektir. Stratejik planlama ile ilgili eğitim almış olan öğretmenlerin stratejik planın okula kazandırdıkları boyutuna ilişkin görüşleri, eğitim almayan öğretmenlerin görüşlerinden daha yüksektir. Yöneticilerin stratejik plan çalışanların okul hakkında daha fazla bilgi sahibi olmasını sağlar maddesine yönelik görüşlerinin düzeyi öğretmenlerin aynı maddeye ilişkin görüşlerinin düzeyinden daha yüksektir. Yöneticilerin stratejik plan hazırlama sürecinde tüm çalışanların katkısı gerekmektedir maddesine yönelik görüşlerinin düzeyi öğretmenlerin aynı maddeye ilişkin görüşlerinin düzeyinden daha yüksektir. Öğretmenlerin stratejik plan hazırlama sürecinde öğrenci ve velilerden destek alınmalıdır maddesine yönelik görüşlerinin düzeyi yöneticilerin aynı maddeye ilişkin görüşlerinin düzeyinden daha yüksektir. Yöneticilerin stratejik plan okulun her türlü ihtiyacının belirlenmesini sağlar maddesine yönelik görüşlerinin düzeyi öğretmenlerin aynı maddeye ilişkin görüşlerinin düzeyinden daha yüksektir. Demirkaya (2007) ve Uluğ (2007) tarafından yapılan araştırma sonuçlarına göre ise, stratejik planlama çalışmalarına gereken katılımın sağlanmadığı, planlamaların okulun ihtiyaçlarına cevap vermediği sonucuna varılmıştır. Bu sonuçlar genel olarak böyle iken, yazarlar tarafından yapılan araştırma sonuçlarında yöneticilerin görüşleri ile öğretmenlerin görüşleri farklılık göstermektedir. Yöneticiler öğretmenlere göre daha olumlu düşünmektedirler. Kıdemi 1-5 yll olan öğretmenlerin stratejik plan hazırlama süreci boyutuna ilişkin görüşleri, kıdemi 16-20 yıl olan öğretmenlerin görüşlerinden daha yüksektir. Kıdemi 11-15 yll olan öğretmenlerin stratejik plan hazırlama boyutuna ilişkin görüssleri, kıdemi 16-20 yıl olan öğretmenlerin görüşlerinden daha düşüktür. Stratejik planlama ile ilgili eğitim almış olan öğretmenlerin stratejik planın okula kazandırdıkları boyutuna ilişkin görüşleri eğitim almayan öğretmenlerin görüşlerinden daha yüksektir. Erkek yöneticilerin stratejik planın hazırlanma süreci boyutlarına ilişkin görüşleri kadın yöneticilerin görüşlerinden daha yüksektir.

Şener (2009) tarafından yapılan araştırmada ise, stratejik planlamaya yönelik olarak, yüksekokul mezunu yönetici ve öğretmenlerin görüşlerinin düzeyinin, eğitim enstitüsü mezunlarına göre daha yüksek olduğu, yöneticiler ile öğretmenlerin görüşleri arasında anlamlı farklılıkların olduğu, ayrıca bazı demografik özelliklere göre (yaşa, cinsiyete göre) stratejik planlamaya yönelik görüşlerinin farklılık gösterdiği ortaya çıkmıştır. Yazarlar tarafından yapılan araştırma sonuçlarına göre ise, yönetici ve öğretmenlerin farklı eğitim seviyesi değişkenlerine göre her birinin görüşleri arasında anlamlı bir fark ortaya çıkmamıştır. Ancak her iki grupta da yüksek lisans ve doktora yapan öğretmen ve yöneticilerin stratejik planlamanın uygulanabilirliği ölçeğindeki boyutlara ilişkin görüşlerinin düzeyi diğer eğitim seviyelerine göre yüksek çıkmıştır.

Altınkurt (2010), milli eğitim müdürlüğü çalışanları ve okul yöneticilerinin stratejik planlamaya ilişkin tutumları adlı çalışmasında, Kütahya İl Milli Eğitim Müdürlüğü çalışanlarının ve okul yöneticilerinin stratejik planlamaya ilişkin tutumlarının olumlu olduğu belirlemiştir. Ancak azımsanmayacak oranda katılımcı, güvensizlik ve direnç gibi olumsuz tutumlara sahiptir. Araştırma bulguları, çalışanların stratejik planlamaya karşı duydukları güvensizlik ve dirence ilişkin temel nedenin bilgi eksikliği olduğunu ortaya koymaktadır. 
Memduhoğlu ve Uçar (2012), yönetici ve öğretmenlerin stratejik planlama algısı ve okullarda mevcut Stratejik planlama uygulamalarının değerlendirilmesi adlı araştırmasında, yönetici ve öğretmenlerin stratejik planlama konusunda olumlu bir algıya sahip oldukları, buna karşın mevcut stratejik planlama uygulamalarının amacına uygun olarak yürütülmediğini düşündükleri, ayrıca yönetici ve öğretmenlerin stratejik planlama algıları ile okullardaki mevcut stratejik planlama uygulamalarına ilişkin görüşleri arasında zayıf bir ilişki olduğu sonucuna ulaşmışlardır. Yanpar, Kılıç ve Üredi (2010), çalışmalarında ilk ve orta öğretim okul müdürlerinin stratejik planlama kavramına ve amaçlarına ilişkin bilgilerinin yeterliği olduğu, ancak uygulamada eğitim eksikliğinden ve ekonomik yetersizliklerden kaynaklanan sorunlar olduğu; bu sorunların da hizmet içi eğitimler ve finansal destek ile çözülebileceği yönünde görüş bildirdikleri sonucuna ulaşmışlardır. Özgan, Baş ve Sabancı (2011) çalışmalarında, okul stratejik planlarında yer alan amaçların; akademik başarı, sosyal etkinlikler ve fiziksel ihtiyaçlar kategorilerinden oluştuğu sonucuna ulaşmışlardır. Okulların, mesleki rehberliğin yapılması ve teknolojik alt yapının geliştirilmesinde kısa ve orta süreli hedeflerine genellikle ulaştıkları saptanmıştır. Stratejik planların temelini, öğrencinin akademik gelişimine katkıda bulunmak olduğunu tespit etmişlerdir.

Araştırmanın ikinci kısmını oluşturan izleme raporları incelendiğinde, okulların 2011 yılına ait 29 stratejik amacının olduğu, bu amaçlara ait 38 adet stratejik hedefin ve bu hedefleri gerçekleştirmeye yönelik 105 performans/faaliyet/projenin olduğu görülmüştür. Okulların 2011 yll izleme raporlarında belirttikleri bu 105 performans göstergesinden 61 tanesinin 2011 yılına, 44 tanesinin ise sadece 2011 yılını değil, daha sonraki yılları da kapsadığı görülmüştür. Buna göre izleme raporları, 2011 yılına ait performansın \%58'e yakın bir oranını temsil etmektedir diyebiliriz. Ayrıca 2011 yılı stratejik plan izleme raporlarına ait 105 performans göstergesi ve faaliyetten 55'inin (\%53) tamamlandığı, 44 ünün (\%42) devam ettiği, $6 \operatorname{sinın~(\% 5)~da~iptal~edildiği~}$ görülmüştür. Faaliyet ve performans göstergesinin tamamının maliyet yetersizliği veya ödenek çıkmaması nedeniyle iptal edildiği belirlenmiştir.

Araştırmada elde edilen bulgulara dayalı olarak aşağıdaki öneriler geliştirilebilir:

- Stratejik planlama bir ekip işidir. Bu şekilde planlamanın içinde bireysel kararlardan çok ekip kararları hâkim olacaktır. Bu yüzden özellikle öğretmenlerin planlama çalışmalarına tam katılımları sağlanmalıdır.

- Araştırmada da bir eksiklik olarak görülen stratejik planlama ile ilgili eğitim seminerleri hem yöneticilere hem de öğretmenlere verilmesi gereklidir.

- Stratejik plan çalışma ekiplerinde bulunma öğretmenlere ve yöneticilere bir zorunlulukmuş gibi değil, gereklilik olarak anlatılmalı ve katılımları gönüllülük esasına dayalı olarak sağlanmalıdır. Hatta bu ekiplere katılımı teşvik amaçlı ekip çalışma saatleriyle ilişkili olarak belirli bir ek ders ücreti ödenebilir. 


\section{Kaynaklar}

Akgemici, T. (2007). Stratejik yönetim. Ankara: Gazi Kitabevi.

Altınkurt, Y. (2010). Milli Eğitim Müdürlüğü çalışanları ve okul yöneticilerinin stratejik planlamaya ilişkin tutumları. Kuram ve Uygulamada Eğitim Bilimleri, 10(4), 1927-1968.

Balc1, A. (1995). Örgütsel gelişme. Ankara: Personel Eğitim Merkezi.

Bryson, J. M. (1995). Strategic planning for public and nonprofit organizations (A Guide to Strengthening and Sustaining Organizational Achievement), San Francisco: Jossey Publishers.

Bursalığlu, Z. (2002). Okul yönetiminde yeni yapı ve davranış. Ankara: PegemA Yayıncılık.

Çelik, V. (1994). Etkili bir okul için stratejik yönetim. Eğitim ve Bilim Dergisi, 18(93), 30.

Dedeoğlu, B. (2003). Uluslararası güvenlik ve strateji. İstanbul: Derin Yayınları.

Demirkaya, D. (2007). "İlköğretim okullarında stratejik planlama uygulamalarının değerlendirilmesi” (Yayınlanmamış yüksek lisans tezi), Ankara Üniversitesi Eğitim Bilimleri Enstitüsü, Ankara.

Drucker, P. F. (1999). 21. Yüzyıl için yönetim tartışmaları. (Bahçıvangil, İ. Gülenay G. Çev.). İstanbul: Epsilon Yayınevi.

EARGED. (2007). Planlı okul gelişim modeli. “Okulda Stratejik Yönetim”, Ankara.

Eren, E. (2002), Stratejik yönetim ve işletme politikası. İstanbul: Beta Yayınları.

Gary, Y. (1990). Skills for managers and leaders. USA: PrenticeHall.

Kabaday1, R. (1999). Stratejik planlama ve eğitim. Verimlilik Dergisi, 2, 143-154.

Karasar, N. (2009). Bilimsel araştırma yöntemi. Ankara: Nobel Yayın Dağıtım.

Kırım, A. (2004). Yeni dünyada strateji ve yönetim, İstanbul: Sistem Yayınc1lık.

Kocatepe, Ş. (2010). "Eğitimde stratejik planlama ve toplam kalite yönetime uygulamalarının okul yöneticilere tarafindan algılanması” (Yayınlanmamış yüksek lisans tezi), Maltepe Üniversitesi Sosyal Bilimler Enstitüsü, İstanbul.

Koçel, T. (2003). İşletme yöneticiliği. İstanbul: Beta Basım A.Ş.

Küçüksüleymanoğlu, R. (2004). "İlköğretim okullarında stratejik planlama çalışması (Bursa ili Canaydın İlköğretim Okulu örneği)” (Yayınlanmamış doktora tezi), Anadolu Üniversitesi, Eğitim Bilimleri Enstitüsü, Eskişehir.

MEB. (2002). Okul gelişim modeli. Planlı Okul Gelişimi. Ankara: MEB Yayınları.

MEB. (2005). Eğitimde kalite ödülü el kitabı. Ankara: Strateji Geliştirme Başkanlığı.

MEB. (2010). Millî Ĕgitim Bakanlığı Strateji Geliştirme Başkanlı̆̆ı 2010-2014 Stratejik Planı http://sgb.meb. gov.tr/MEBStratejikPlan.pdf). 01/09/2014 tarihinde erişilmiştir.

Memduhoğlu, H. B. \& Uçar, İ. H. (2012). Yönetici ve öğretmenlerin stratejik plan algısı ve okullarda mevcut stratejik planlama uygulamalarının değerlendirilmesi, Mehmet Akif Ersoy Üniversitesi Eğitim Fakültesi Dergisi, 12(23), 234- 256.

Mütercimler, E. (2006). Yüksek stratejiden etki odaklı harekâta geleceği yönetmek (1.Basım), İstanbul: Alfa Yayınları.

Özgan, H., Baş, M. \& Sabanc1, C. (2011). Liselerin okul stratejik planlarında yer alan stratejik amaçlara ve hedeflere ulaşma düzeylerinin incelenmesi. E-Journal of New World Sciences Academy Education Sciences, 6(2), 1453-1462.

Özmen, F. (1997). "Fırat ve İnönü Üniversitelerinde örgütsel çatışmalar ve çatışma yönetimi yaklaşımları" (Yayınlanmamış doktora tezi), Frrat Üniversitesi, Sosyal Bilimler Enstitüsü, Elazığ.

Robbins, S. P. (1984). Management: Concepts and Practices, Englewood Cliffs, New Jersey: Prentice Hall Inc. 
Şener, T. (2009). "Eğitimde stratejik planlama" (Yayınlanmamış yüksek lisans tezi), Kadir Has Üniversitesi Sosyal Bilimler Enstitüsü, İstanbul.

Şimsek, M. S. (2008). Yönetim ve organizasyon. Konya: Günay Yayınevi.

Thompson, A., \& Strickland, A. J. (1996). Strategic management-concepts \& cases. Princeton: Irwin McGraw - Hill Publishing.

Üzün, C. (2000). Stratejik yönetim ve halkla ilişkiler. İzmir: Eylül Yayınları.

William, H. N. (1979). Yönetim sevk ve idare. ( Sürgit K. Çev.). Ankara: TODAİE Yayınları.

Yanpar, Y. T., Kılıç, F. \& Üredi, L. (2010). Stratejik planlama uygulamalarına ilişkin ilk ve orta öğretim okul müdürlerinin görüşleri. Uluslararası Avrasya Sosyal Bilimler Dergisi, 1(1), 38-50. 
